the lemming Dicrostonyx groenlandicus, males kill the offspring of unrelated males, but do not attack their own young ${ }^{8}$. Young males of the gerbil Meriones unguiculatus will normally kill and eat any pups. However, experimental exposure to a pregnant female inhibits this behaviour ${ }^{9}$. As gerbils are monogamous and territorial, any pups which a male meets after an encounter with a pregnant female in nature are likely to be his own and hence to share a high proportion of his genes. In mice, however, in which males will mate with any available female, destruction of young by adult males continues throughout life. Pregnant female mice exposed to a novel male reabsorb the fetuses which have resulted from a previous mating; this 'prenatal cannibalism' may have evolved in response to the high probability of the young being eaten at birth by the unrelated male ${ }^{10}$. Such kinship effects may influence the demography of vertebrate populations. In pike, attacks on unrelated individuals mean that fewer young are produced in ponds founded by mixing two full-sib families than when members of only one family are used" ${ }^{\prime \prime}$.

Kin selection is particularly likely to reduce cannibalism in organisms whose local populations are relatively inbred, so that their members have a rather high proportion of genes in common. Wade's experiments on Tribolium show this clearly, as an avoidance of sibling cannibalism evolved only in inbred populations. In experiments in which there was random mating among the evolving stocks, no differences appeared among populations offered related or unrelated eggs. Computer. simulations show that even a small amount of inbreeding greatly hastens the evolution of altruistic behaviour ${ }^{12}$. It is often assumed that the social groups found in large mammals represent locally inbred populations and that their close kinship leads to the evolution of altruism and the avoidance of cannibalism among their members. However, detailed observation of individual mating patterns or the analysis of relatedness using genetic markers in lions and primates show that the members of a social group are not always particularly closely related to each other ${ }^{13,14}$ so that their behaviour cannot be explained simply by assuming that kin selection is operating.

A less ambiguous method of testing the importance of kinship effects has recently

Polis, G.A. A. Rev. Écol. Syst. 12, 225 (1981)

Cuff, W.R. Con. J. Zool. 58, 1504 (1980)

. Sherman, P. in Natural Selections and Social Behaviour (eds Alexander, R.D. \& Tinkle, D.) (Chiron, New York, 1980).

Polis, G. A. Behav. Ecol. Sociobiol. 7, 25 (1980)

Wade, M.J. \& McCauley, D.E. Evolution 34, $799(1980)$

McCauley, D.E. \& Wade, M. J. Evolution 34, 813 (1980)

Macauley, D.E. \& Wade, M.J. Evolution

Mallory, F.F. \& Brooks, R.J. Nature 273, 144 (1978).

Elwood, R.W. Anim. Behav. 28, 1188 (1980).

Hardy, S.B. Ethol. Sociobiol, 1, 13 (1979).

Bry, C. \& Gillet, C. Reprod. Nutr. Dev. 20, 173 (1980).

Wade, M.J. \& Breden, F. Evolution 35, 844 (1981).

Packer, C. \& Pusey, A.E. Nature 296, 740 (1982).

Melnick, D.J. Genetics 100, $546(1982)$

Foltz, D.W. et al. Biol. J. Linn. Soc. 17, 225 (1982) become available with the realization that many hermaphrodite animals reproduce by self-fertilization ${ }^{15}$. This represents very close inbreeding. It might therefore provide an unusually direct way of examining the role of kinship in aggression and cannibalism, as in those species in which both selfing and outcrossing forms occur in the same population, outbreeders should be more likely to attack their relatively distant relations than are selfers to destroy their close kin.

It is already clear that to cannibalize unrelated animals may increase the probability of survival of an aggressor's own genes. This may be an important factor in the evolution of behaviour, however much it conflicts with the widespread view that the struggle for existence is usually tempered by avoiding fatal interactions between members of the same species.

\title{
Increasing atmospheric carbon dioxide and its consequences
}

\section{from John G. Lockwood}

NUMEROUS forecasts of the increase in atmospheric $\mathrm{CO}_{2}$ that will result from the burning of fossil fuels have been made. The IIASA Energy Systems Programme ${ }^{1}$ predicts an atmospheric $\mathrm{CO}_{2}$ concentration of 430 to 500 p.p.m.v. in 2030 while The World Climate Programme ${ }^{2}$ suggests values of 410 to 490 p.p.m.v. in 2025 . Concentrations as low as 200 p.p.m.v. have been estimated for the end of the last galciation $^{3,4}$, even though levels may have been considerably higher in the more remote geological past. Recent observations show that the global mean $\mathrm{CO}_{2}$ concentration in the atmosphere has increased from about 315 p.p.m.v. in 1958 to about 335 p.p.m.v. in 1979 , a considerable increase over nineteenth century pre-industrial levels estimated at about 290 p.p.m.v.

Armed with forecasts of future fossil fuel needs and $\mathrm{CO}_{2}$ production, how do we estimate the effect that these increasing concentrations will have? At a recent gathering in Norwich*, Gates (Oregon State University) argued that the problem is best approached using general circulation models (GCMs), which have the ability to portray many of the nonlinear feedback processes which serve to regulate atmospheric (and hence climatic) changes. The first application of a GCM to the $\mathrm{CO}_{2}$ climate problem $^{5}$ used an idealized geography with a swamp-like ocean and annually averaged insolation, and predicted that a doubling of atmospheric $\mathrm{CO}_{2}$ would result in a $2-3 \mathrm{~K}$ increase of globally averaged surface air temperature. This first attempt also showed the warming to be several times larger in high latitudes than at the Equator, and the globally averaged precipitation to be increased by a few per cent.

In subsequent simulations with GCMs

-The Royal Meteorological Society summer meeting on 'Climatic effects of increasing atmospheric $\mathrm{CO}_{2}$ ' was held on $15-16 \mathrm{July}$ 1982.

John G. Lockwood is in the School of Geography, University of Leeds, Leeds LS2 gJT. including more realistic geography and seasonal variations, generally similar results (global temperature increases of about $2 \mathrm{~K}$ for a doubling of $\mathrm{CO}_{2}$ ) have been found; such GCMs indicate that the largest warming will occur in the winter in high latitudes, with the summer precipitation shifted slightly polewards along with increased surface dryness in mid-latitudes. Flohn (University of Bonn) noted that highlatitude warming could lead to the disappearance of the perennial Arctic seaice and changes in the mass balance of the Antarctic ice sheet. In contrast, the zeroorder, purely optical effect of doubling atmospheric $\mathrm{CO}_{2}$, according to Kandel (CNRS), would be an increase of about $0.2 \mathrm{~K}$ in surface temperature, but depending on what is assumed about various feedback mechanisms, such as atmospheric temperature, humidity, lapse rate, evaporation and clouds, this zeroorder sensitivity may be multiplied by a factor ranging from 0.1 to 50 .

Detection studies are now being directed by Wigley and Kelly (University of East Anglia) towards isolating those parts of observed climate fluctuations that are attributable to increasing atmospheric $\mathrm{CO}_{2}$. This involves detecting what is at present a relatively weak signal in the presence of considerable noise. Climatic changes during the past century can partly be explained by increasing atmospheric $\mathrm{CO}_{2}$ with contributions from volcanic activity. However, on the basis of the results so far it seems unlikely that a $\mathrm{CO}_{2}$ signal will be detected with high confidence before 1990 . Nevertheless, it looks as though $\mathrm{CO}_{2}$ induced warming could become a major climatic factor by the middle of the next century.

\footnotetext{
1. IIASA Energy Systems Program Energy in a Finite World (Ballinger, 1981).

2. World Climate Program On the Assessment of the Role of $\mathrm{CO}_{2}$ on Climate Variations and their Impact (WMO, Geneva, 1981).

3. Oeschger, H. el al. in Interactions of Energy and Climate (eds Bach, W., Pankrath, J. \& Williams, J.) 107 (Rendel, 1980).

5. Manabe, S. \& Wetherald, R.T. J. atmos. Sci. 32, 3 (1975).
} 